\title{
Genetic diversity in Mexican wild populations of the Great Curassow (Crax rubra)
}

\author{
Jonathan Morales-Contreras $^{1,3}$, Patricia Escalante ${ }^{1 *} \mathbb{C}$ \& Noemí Matías-Ferrer ${ }^{1,2} \mathbb{C}$ \\ ${ }^{1}$ Universidad Nacional Autónoma de México, Instituto de Biología, A. P .70-153, 04510, Coyoacán, \\ Ciudad de México, México \\ ${ }^{2}$ Endémicos Insulares, A. C. Celestino Martínez 23, 91500 Coatepec, Veracruz, México \\ ${ }^{3}$ El Colegio de la Frontera Sur, A. P. 029290, San Cristóbal de Las Casas, Chiapas, México \\ *Corresponding author: Patricia Escalante, e-mail: tilmatura@ib.unam.mx
}

MORALES-CONTRERAS, J., ESCALANTE, P., MATÍAS-FERRER, N. Genetic diversity in Mexican wild populations of the Great Curassow (Crax rubra). Biota Neotropica 19 (1): e20180649, 2019. http://dx.doi.org/10.1590/1676-0611-BN-2018-0649

\begin{abstract}
The Great Curassow (Crax rubra) is a Neotropical bird with a wide distribution; it is classified under different threat categories and is listed as a vulnerable species by the IUCN. The Official Mexican Standard, the NOM-059SEMARNAT-2010, indicates that the Great Curassow is a threatened species, and the subspecies Crax rubra griscomi, which is restricted to the island of Cozumel, is classified as critically endangered. Habitat loss and fragmentation, hunting, overexploitation, and illegal trade are among the main factors that have placed the bird at an endangered status. The objective of the present study was to determine the genetic structure and variation of the species within the Mexican populations of Crax rubra by using three mitochondrial markers, and one nuclear marker (COI, ND2, Cyt b, and MUSK). We used 47 samples obtained by noninvasive collection (feathers) including the two different color phases of the female plumage: dark brown and barred (rare in Mexico). Gene flow between the remaining populations is recent and extensive, even between the continental and the island population (C. r. griscomi). The results indicate that the subspecies C. r. rubra and C. r. griscomi do not present a marked genetic differentiation because the second exhibits an exclusive haplotype and a shared haplotype. With this study, we provide the first genetic-geographic approximation of the curassow in Mexico, where a gradual geographic differentiation is observed between the western and eastern populations of the Isthmus of Tehuantepec, and we provide a baseline for future studies. Finally, the information obtained indicates that important genetic diversity persists in the Mexican populations of the Great Curassow and that sufficient conservation within the ecosystems of these subspecies can be obtained by protecting them from overexploitation and by conserving and restoring their habitat.

Keywords: Cracids, noninvasive collection, genetic variability, mitochondrial genes, nuclear gene, gene pool, conservation.
\end{abstract}

\section{Diversidad genética en poblaciones silvestres mexicanas del hocofaisán (Crax rubra)}

Resumen: El hocofaisán (Crax rubra) es un ave de la región Neotropical con amplia distribución, que se encuentra en diferentes categorías de riesgo, por la IUCN está catalogada como una especie Vulnerable. Anivel nacional, dentro de la NOM059-SEMARNAT-2010 está considerada como una especie amenazada, y la subespecie Crax rubra griscomi restringida a la isla de Cozumel, está categorizada como en peligro de extinción. Entre los factores principales por los que se encuentra en grave riesgo, destacan la pérdida y fragmentación del hábitat, la cacería, la sobreexplotación, la extracción y el comercio ilegal. El objetivo del presente estudio es conocer la estructura y variación genética de la especie dentro de las poblaciones silvestres mexicanas de Crax rubra, mediante el uso de tres marcadores mitocondriales y uno nuclear (COI, ND2, Cyt b y MUSK). A partir de 47 muestras obtenidas mediante colecta no invasiva (plumas) que incluyen las dos fases de plumaje de la hembra: café oscura y barrada (rara en México). Se observó que el flujo génico entre las poblaciones remanentes es reciente y extenso, incluso entre las poblaciones continentales y la isleña (C. r. griscomi). Los resultados indican que las subespecies $C$. r. rubra y C. r. griscomi no presentan una marcada diferenciación genética dado que la segunda presentó un haplotipo exclusivo y uno compartido. Con el presente estudio brindamos la primera aproximación genético-geográfica del hocofaisán en México y una línea de base para futuros estudios, en el que se observa una diferenciación geográfica gradual entre las poblaciones del oeste y del este del Istmo de Tehuantepec. Finalmente, la información obtenida indica que en las poblaciones mexicanas del hocofaisán persiste una diversidad genética importante y que su conservación en los ecosistemas puede ser suficiente mediante la protección a la sobreexplotación, la conservación y restauración de su hábitat. Palabras clave: Crácidos, colecta no invasiva, variabilidad genética, genes mitocondriales, gen nuclear, acervo genético, conservación. 


\section{Introduction}

The Cracidae is a bird family native to the Neotropical region, and these birds constitute one of the most vulnerable groups found on the American continent (Delacour \& Amadon, 2004; International Ornithological Union, 2018). In Mexico, eight species of Cracids are present, of which five are listed by the International Union for the Conservation of Nature (IUCN) under some endangered category (Pinilla-Buitrago et al., 2014), with the Great Curassow Crax rubra (Linnaeus, 1758) being considered vulnerable (BirdLife International, 2016). Additionally, according to the Official Mexican Standard NOM059-SEMARNAT-2010, the nominal species is considered threatened, and the endemic subspecies C.r. griscomi (Nelson, 1926) is considered endangered. C. r. rubra is distributed from southern Tamaulipas to the Yucatan Peninsula through the central plateau of the Isthmus of Tehuantepec and continues through Central America, with its range culminating west of the Andes in Colombia and Ecuador (del Hoyo, 1994), whereas C. r. griscomi is found exclusively on the Island of Cozumel. Unlike other cracids, C. rubra presents a marked sexual dimorphism (Delacour \& Amadon, 2004), and the plumage of females have three different color patterns, which are described as the dark brown phase (the most common in Mexico), the barred phase (rare to observe, but present in the country), and the red phase (absent in Mexico). The Cozumel Curassow is distinguished by its reduced body size in comparison to that of the continental curassow (Nelson, 1926; Martínez-Morales, 1996).

The Great Curassow plays a key role in the regeneration of ecosystems due to its highly complex dynamics in seed dispersal and predation (Sedaghatkish, 1996; Muñoz \& Kattan, 2007). Given its high sensitivity to the destruction of its habitat (Silva \& Strahl, 1997), the species is considered an indicator of habitat quality. Due to its large body size, the Great Curassow is very important within the trophic chains as prey for mammals and raptors (Aranda \& Sánchez-Cordero, 1996; Chinchilla, 1997; Delacour \& Amadon, 2004). Additionally, in several indigenous communities, it is an important source of food, since it has the largest biomass of birds killed by hunters (Begazo, 1997; PérezIrineo \& Santos-Moreno, 2017).

Estimates of population densities of C. r. rubra indicate that 6,700 to 40,000 individuals are found within the Great Curassow distribution, with a decreasing trend (BirdLife, 2016), whereas, in 2005, C. r. griscomi had an estimated population size of approximately 372 individuals, with its conservation status currently unknown (Martínez-Morales et al., 2009). Among the main threat factors for C. rubra are habitat loss, fragmentation, or deterioration, hunting, overexploitation, illegal trade, and climate change (Begazo, 1997; Silva \& Strahl, 1997; Brooks \& Strahl, 2000; Baur, 2008; Kattan et al., 2015; Peterson et al., 2015). Because it is located on an island, C. r. griscomi is more susceptible to the introduction of exotic species, hurricanes, urbanization, and the increase in tourism infrastructure (Martínez-Morales, 1999; Cuarón et al., 2009).

Regarding genetic diversity, habitat reduction in cracids may result in a decrease in genetic diversity, as suggested for $C$. fasciolata (Pereira \& Wanjtal, 2001; Goncalves et al., 2010). In Mexico, the main risk factors could be overexploitation and habitat loss and reduction. Recent estimates indicate that the country has lost $82 \%$ of its original forest cover and that this cover continues to decline (Koleff et al., 2012; Hansen et al., 2013). Given that the distribution of the species is linked to primary forests, C. rubra populations in the country are already isolated and extirpated in most of their historical distribution areas. Therefore, to propose a solid foundation for its conservation within the country, the present work aims to assess the genetic diversity and differentiation among the main wild populations throughout its distribution in Mexico.

\section{Material and Methods}

\section{Samples}

The sampling strategy was carried out as follows: first, the potential distribution of Crax rubra was determined from exclusive records from Mexico obtained from the Database of Global Occurrences of Cracids (Pinilla-Buitrago et al., 2014). Additionally, more recent records that extend the distribution of C. rubra (Hernández-Pérez et al. 2014) were included. Once the potential distribution map was obtained, the best-conserved areas were selected for fieldwork, which included the following natural protected areas: El Cielo Biosphere Reserve (Tamaulipas), Sierra Gorda Biosphere Reserve (Querétaro), Los Tuxtlas Biosphere Reserve (Veracruz), Reserva Campesina de Los Chimalapas (Oaxaca), Calakmul Biosphere Reserve (Campeche), Montes Azules Biosphere Reserve (Chiapas), El Triunfo Biosphere Reserve (Chiapas), and the Palenque National Park (Chiapas) (Figure 1, STable 1).

Table 1. Genetic heterogeneity statistics (Kxy= average number of nucleotide differences between populations. Measure of genetic differentiation= Fs, Gst,Nst $\Delta$ st, $\gamma \mathrm{st}$, and $\mathrm{Da}=$ nucleotide substitutions per site between populations) at the three mitochondrial genes of the 10 Mexican populations of the curassow (Crax rubra). Populations groups based on the network of their geographic correlation and similarity of habitat.

\begin{tabular}{|c|c|c|c|c|c|c|c|c|}
\hline Population 1 & Population 2 & Kxy & Gst & $\Delta \mathbf{s t}$ & $\gamma \mathbf{s t}$ & Nst & Fst & Da \\
\hline Cozumel Island & Escarcega-Conhuas & 4.6 & 0.0708 & 0.00006 & 0.039 & 0.03293 & 0.03259 & 0.00005 \\
\hline Cozumel Island & Veracruz_Oaxaca & 5.5 & 0.0423 & 0.00022 & 0.136 & 0.19022 & 0.18990 & 0.00037 \\
\hline Cozumel Island & Chiapas_Belice_Qroo & 3.4 & -0.0059 & 0.00016 & 0.166 & 0.02806 & 0.02778 & 0.00003 \\
\hline Escarcega-Conhuas & Veracruz_Oaxaca & 5.7 & 0.0183 & 0.00017 & 0.095 & 0.14037 & 0.14051 & 0.00028 \\
\hline Escarcega-Conhuas & Chiapas_Belice_Qroo & 3.8 & -0.0003 & 0.00004 & 0.029 & 0.01539 & 0.01535 & 0.00002 \\
\hline Veracruz_Oaxaca & Queretaro_Tamaulipas & 3.5 & 0.2324 & 0.00020 & 0.162 & 0.29825 & 0.29841 & 0.00037 \\
\hline Veracruz_Oaxaca & Chiapas_Belice_Qroo & 4.3 & 0.0014 & 0.00017 & 0.120 & 0.13045 & 0.13042 & 0.00020 \\
\hline Queretaro_Tamaulipas & Chiapas_Belice_Qroo & 4.2 & 0.2953 & 0.00054 & 0.533 & 0.68898 & 0.68889 & 0.00104 \\
\hline
\end{tabular}




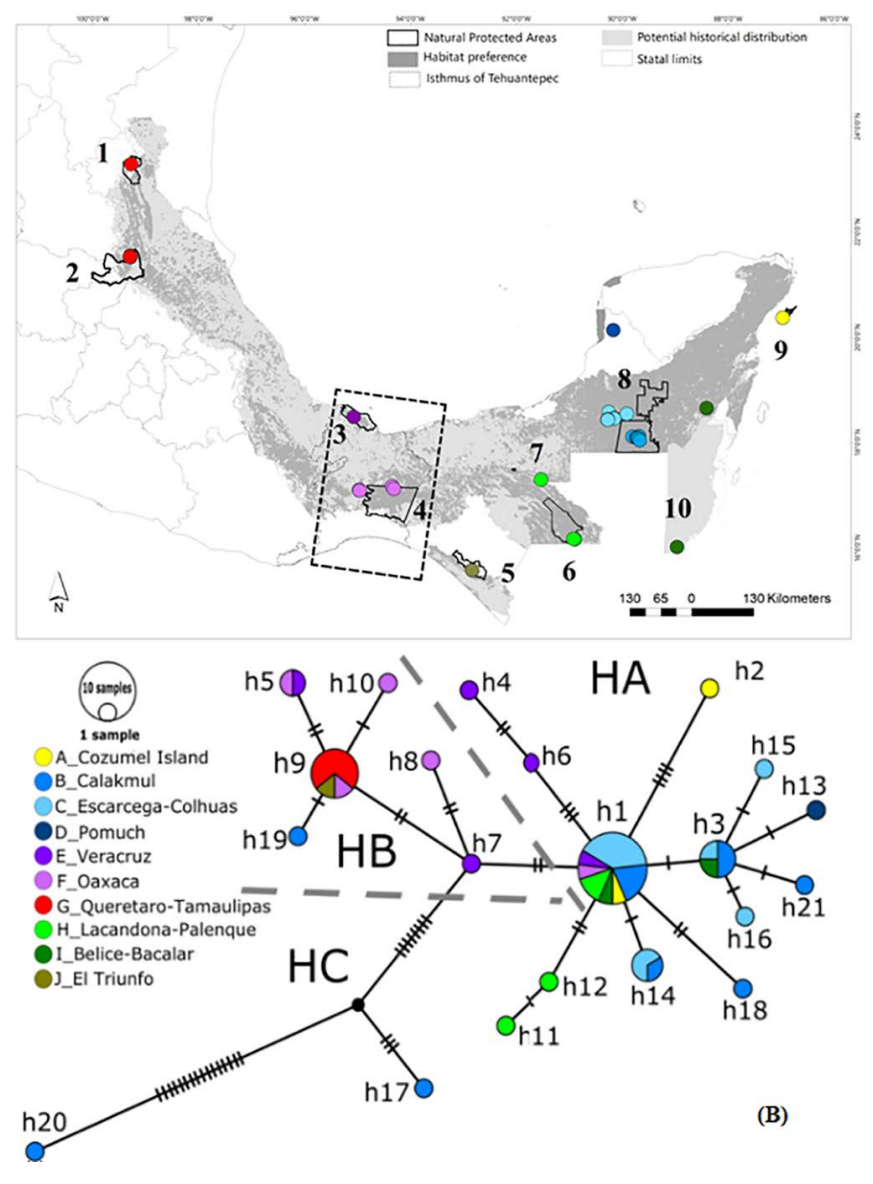

Figure 1. (A) Collection sites throughout the Crax rubra distribution range within Mexico. The circles represent the records of the individuals collected. Potential historical distribution of Crax rubra (light gray) and current preferred habitat (dark gray). The polygons show the boundaries of the protected areas. (1) El Cielo Biosphere Reserve (Tamaulipas), (2) Sierra Gorda Biosphere Reserve (Querétaro), (3) Los Tuxtlas Biosphere Reserve (Veracruz), (4) Campesina Reserve of Los Chimalapas (Oaxaca), (5) El Triunfo Biosphere Reserve (Chiapas), (6) Montes Azules Biosphere Reserve (Chiapas), (7) Palenque National Park (Chiapas), (8) Calakmul Biosphere Reserve (Campeche), (9) Cozumel Island Biosphere Reserve (Quintana Roo), and (10) Belize. (B) Haplotype network for Mexican populations of the Great Curassow (Crax rubra). Barrs indicate numbers of individual mutation, and the size of the circle represents the frequency of each haplotype. The dotted gray line represents the HA and HB haplogroups relatively separated by the Isthmus of Tehuantepec, and the $\mathrm{HC}$ haplogroup present in Calakmul.

Because the Great Curassow is an evasive species, the acquisition of direct samples is difficult. A noninvasive sampling method using biological material (feathers) was undertaken for the purpose of not disturbing or stressing individuals. An intensive survey was carried out for collecting samples from perching, or scratching sites being located through vocalizations. To distinguish among individuals, feathers were collected at a minimum distance of $5 \mathrm{~km}$ from other samples and sorted in male (black feathers) and female (dark brown phase and barred phase). Additionally, nine samples were included, from scientific collections: Bird Collection of the Museum of Mayan Biodiversity, UACAM (two feathers), and Museum of Zoology, Faculty of Sciences, UNAM (three tissues); from Oaxaca (blood preserved on FTA Whatman cards samples from two adults and a chick), a donation from Belize (one feather), and two samples (feathers) from Cozumel Island (C. r. griscomi).

\section{Sequences}

DNA extraction was performed with a DNeasy Blood \& Tissue extraction kit (Qiagen); in particular, the feathers were processed using the method used by Morales-Contreras et al. (2016). To reduce the probability of obtaining pseudogenes (Pereira \& Baker, 2004a), three mitochondrial regions larger than $1000 \mathrm{bp}$ were amplified using the polymerase chain reaction (PCR) of Cytochrome Oxidase I (COI), NADH subunit 2 (ND2), and Cytochrome b (Cyt b) and the noncoding nuclear gene MUSK (muscle skeletal receptor tyrosine kinase). A platinum Taq PCR kit (Invitrogen) was used, and the reaction volume of the PCR sample was $12 \mu$ : DNA Taq polymerase (1 unit), 1X PCR buffer, $1.5 \mathrm{mM} \mathrm{MgCl} 2,10 \%$ Trehalose, $0.2 \mathrm{mM}$ dNTP mix, $0.2 \mu \mathrm{M}$ of forward and reverse primers, and 2 to $3 \mu \mathrm{L}$ of DNA. We used the primers Ltyr (Tavares \& Baker, 2008), H8205 (Pereira \& Baker, 2004b), COIBird F1 (Hebert et al., 2004), and internal primers AwCintF4 and COIBird R2 (Kerr et al., 2009) to amplify COI. For Cyt b, L14841 (Kocher et al., 1989) and H4a (Harshman, 1996) primers were used. L5215 (Hackett, 1996) and H6313 (Sorenson et al., 1999) primers to ampify ND2. MUSK F and MUSK R (Barker, 2004) primers were used for MUSK gene. The amplification conditions for the three genes were: a denaturation of $94^{\circ} \mathrm{C}$ for $1 \mathrm{~min}$, followed by 40 cycles at $94^{\circ} \mathrm{C}$ for $45 \mathrm{seg}, 58^{\circ} \mathrm{C}$ for $1 \mathrm{~min}$, and $72^{\circ} \mathrm{C}$ for $2 \mathrm{~min}$; and a final extension of $72^{\circ} \mathrm{C}$ for $10 \mathrm{~min}$. Internal primers of COI were amplified with the conditions suggested by Lijtmaer et al. (2012). MUSK was amplified with a denaturation of $94^{\circ} \mathrm{C}$ for $3 \mathrm{~min}$, followed by 35 cycles of $94^{\circ} \mathrm{C}$ for $35 \mathrm{sec}, 48^{\circ} \mathrm{C}$ for $40 \mathrm{sec}$, and $72^{\circ} \mathrm{C}$ for $1 \mathrm{~min}$ and an extension of $72^{\circ} \mathrm{C}$ for $10 \mathrm{~min}$. The products were visualized on $1 \%$ agarose gels and subsequently sent to the Molecular Biology Laboratory of Biodiversity and Health of the Institute of Biology (UNAM) for sequencing.

\section{Phylogenetic analysis and genetic diversity}

The sequences were edited with CodonCode Aligner V5 (CodonCode Corporation). Using MEGA v6 (Tamura et al., 2013), we verified the absence of stop codons for the translation to amino acids, as well as the multiple sequence alignment for each gene, using ClustalW (Thompson et al., 2002). In MESQUITE (Madisson \& Madisson, 2011), the three mitochondrial genes and the MUSK nuclear gene were concatenated. Using DNASP 5.0 (Librado \& Rozas, 2009), number of haplotypes $(H)$, haplotypic diversity $\left(H_{\mathrm{d}}\right)$, nucleotide diversity $(\pi)$, genetic diversity $(\theta)$, and mismatch distribution analysis were calculated. Genetic differentiation was tested through calculation of genetic heterogeneity statistics (Kxy, Gst, $\Delta$ st, $\gamma$ st, Nst, Fst and Da) again in DNASP 5.0, with the three mitochondrial genes for mexican populations of Crax rubra, grouped with their geographic correlation and similarity of habitat network. In PopART, (Leigh \& Bryant, 2015), the haplotype network was constructed using the median-joining algorithm (Bandelt et al., 1999), which is related to the coalescence of the common ancestor. To evaluate the degree of genetic differentiation between and within populations, a molecular variance analysis (AMOVA) was performed. Finally, the Nei genetic distances were obtained for populations according to the geographical distribution of haplotypes.

The phylogenetic reconstruction was done by maximum likelihood (ML) analysis and Bayesian Inference (Irisarri and Zardoya, 2013), with 
the evolution model of nucleotide substitution $\mathrm{TrN}$ with invariant sites I (Reeves, 1992; Tamura and Nei, 1993) obtained under the Akaike information criterion (AIC) with jMODELTEST version 0.1.1 (Reeves, 1992; Posada, 2008). Crax daubentoni (KJ914544.129) and Pauxi pauxi (AF 165473, AF 1654971, KX356255) were included as external groups. The ML analysis was performed with 2000 bootstrap replicates to evaluate branches support using PhyML 3.0 (Guindon et al., 2010). The Bayesian analysis (BY) was performed with Mr. Bayes version 3.2 (Ronquist et al., 2011), with 10 million generations, discarding 25\% of the trees in the burning phase to get the optimal topology. In both analyzes, the evolutionary model of nucleotide substitution previously obtained was used.

\section{Results}

Fifty-nine feathers were collected, of which only three corresponded to the barred phase (C_Escarcega_Conhuas_02, C_Escarcega_Conhuas_03 and B_Calakmul_02). In total, genomic DNA was obtained from 41 feathers and six blood samples, which were also incorporated into the analyses. The MUSK gene was not informative because no nucleotide substitutions were founded in 11 of the sequences obtained, and for that reason it was not included in the phylogenetic analyses. The final data matrix consists of 141 sequences belonging to 47 individuals, of which $1034 \mathrm{bp}$ were from ND2 (position 5140 - 6109 of the mitochondrial genome), 1440 bp were from COI (position 6597 - 8037 of the $m t$ genome), and 1029 bp were from Cyt b (position 14897 - 15933 of the mt genome), and none of the genes exhibited stop codons.

The concatenated sequence data matrix has a total of $3503 \mathrm{bp}$, with $66(1.8 \%)$ variable sites and $26(0.7 \%)$ parsimoniously informative sites. Regarding the diversity indices, the haplotypic diversity (Hd) was high at 0.874 , whereas the nucleotide diversity per site $(\pi)$ was 0.00169 . The average number of nucleotide differences $(\mathrm{k})$ was 4.81 , and the genetic diversity $(\theta)$ per sequence was 12.68 .

In total, 21 different haplotypes were detected sorted in a network containing three main haplogroups. This arrangement showed some geographical congruence with a gradient of frequencies from north to east (Figure 1). Haplogroup HA was formed by the most common haplotype (H1), which includes individuals from most of the populations of southern Mexico and the Yucatan peninsula (green, blue and purple). The second haplogroup (HB) included populations from the North (Querétaro and Tamaulipas, red), with the haplotype of the second-greatest frequency (H9). An individual from the southeastern population (moss green; from El Triunfo, Chiapas), was also included in haplotype H9, which is geographically more isolated within the Mexican distribution. The individuals of Veracruz and Oaxaca (lilac and purple) were represented in the two main haplogroups (HA and HB). The third haplogroup (HC) joins the network through the absence of a haplotype (black color) and included two samples from southern Mexico (Calakmul, Campeche), and these two samples were excluded by eight mutational steps, in addition to three and 16 more steps, respectively. About of the two Cozumel Island samples (C. r. griscomi), one of the individuals presented an exclusive haplotype (H2, yellow) with four mutational steps from $\mathrm{H} 1$, whereas the second sample was included in the haplotype of greatest frequency $(\mathrm{H} 1)$.
The genetic distances within and between populations were almost all extremely low (Supplementary Figure 1), even between C. r. griscomi and C. r. rubra, whose values range from 0 to $0.01 \%$. However, the greatest genetic distance observed was between individuals from Calakmul (B_Calakmul_10) and an individual from Veracruz (E_Veracruz_01), and between the same individual from Calakmul (B_Calakmul_10) and an individual from Cozumel Island (A_Cozumel_Island_02), both with a distance of $1.0 \%$. The analysis of paired distributions (Mismatch) resulted in a bimodal pattern, suggesting an equilibrium and not a population expansion (Figure 2A). In addition, the Tajima's D test revealed negative population changes (-2.17342), which confirm that the population shows stability and not expansion. For the other statistics, 10 populations were considered, which correspond to the geographical distribution (Supplementary Table 1). The $\mathrm{N}_{\mathrm{ST}}$ and $\mathrm{F}_{\mathrm{ST}}$ values showed that the most distant populations are the most differentiated (Table 1); the Belize-Bacalar representatives compared to the Querétaro-Tamaulipas population had the highest genetic differentiation ( $F s t=0.888$ ). According to the analysis of molecular variance (AMOVA), all variation is distributed within the populations with a variance component of 17.762 , which represents $100 \%$ of the genetic variation, whereas among populations, the values are null, which indicates that the gene flow is high and genetic differentiation is low in the species.

The results of the phylogenetic analyses using ML and BY (Figure 2) indicate that C. rubra forms a monophyletic group using $C$. daubentoni and Pauxi pauxi as outgroups, in which the two samples of haplotype HC (Calakmul) separate from the rest of the samples at the base of the clade ( $>60 \%)$. Within this second clade, two main groups are formed and correspond to the other two haplogroups obtained (HA and HB), with bootstrap support $>89 \%$ and a posterior probability equal to 1.0 . The separation of the populations in the Isthmus of Tehuantepec is notable but incomplete. On the one hand, the Querétaro and Tamaulipas populations are grouped (HB), but the group also includes some samples from Oaxaca and southern Chiapas (El Triunfo). On the other hand, the second group (HA) is formed by haplotypes from Veracruz, northern Chiapas, and from the Yucatán Peninsula, and Cozumel Island. In each of the groups, other internal clades with the same support that is greater than $80 \%$ are observed $(\mathrm{pp}=0.9)$.

\section{Discussion}

The potential historical distribution indicates an extensive distribution of C. rubra associated with lowland and highland Neotropical forests in Mexico. However, the current potential distribution reveals low connectivity and isolated populations because of the loss and modification of tropical forests and, consequently, the recent decline of the wild populations of The Great Curassow in Mexico. In disturbed places, no samples or sightings of C. rubra were obtained, although inhabitants of the different localities confirmed the presence of the curassow in recent years (10-15 years). On the other hand, in well-conserved areas (core zones of protected natural areas), most of the time, some indication of the presence of the species in the area was found. For example, in the southern part of their distribution, where the continuity of the primary vegetation is wide, the largest number of 
samples was collected, and the greatest genetic diversity was observed. In the northern part of their distribution, the number of populations was low, and it is where the greatest forest loss has occurred. Additional factors that directly affect the presence of the Great Curassow were confirmed and identified, as subsistence hunting (Chiapas and Oaxaca), or hunting as a recreational activity (some parts of Campeche); the construction of roads throughout the species distribution, land use change, illegal trafficking, and the use of specimens as pets (military camps in Chiapas). Therefore, the conservation of the original vegetation remnants, as well as their connection and protection, is crucial.

The diversification of the Cracidae, which is of Mesoamerican origin, occurred in South America approximately 3 million years ago. Crax rubra is the ancestral species within the genus and recolonized Mesoamerica in recent times, possibly in the Pliocene (Hosner et al., 2016). The recent expansion of cracids may explain the low genetic differentiation observed within Mexican populations of C. rubra and the low genetic structure.
The mismatch analyses revealed that the species has maintained a stable population size and shows no recent expansion, which may imply that wild populations are currently dividing or experiencing a reduction due to fragmentation. We noticed that a gradual geographical differentiation exists from northern to southern and eastern Mexico. With regard to plumage phases of females, they did not show any significant genetic difference, nor exclusive morphological characters of a lineage. The lack of genetic congruence with phases of coloration in the plumage has already been recorded previously (Zink et al., 2005).

In this study, we did not find indications of isolation or reduction of the historical population, possibly due to the prevalence of populations with a moderate size in protected natural areas. However, if the habitat continues to contract and the exploitation pressure does not cease, bottlenecks and loss of genetic diversity could occur as a result of genetic drift.

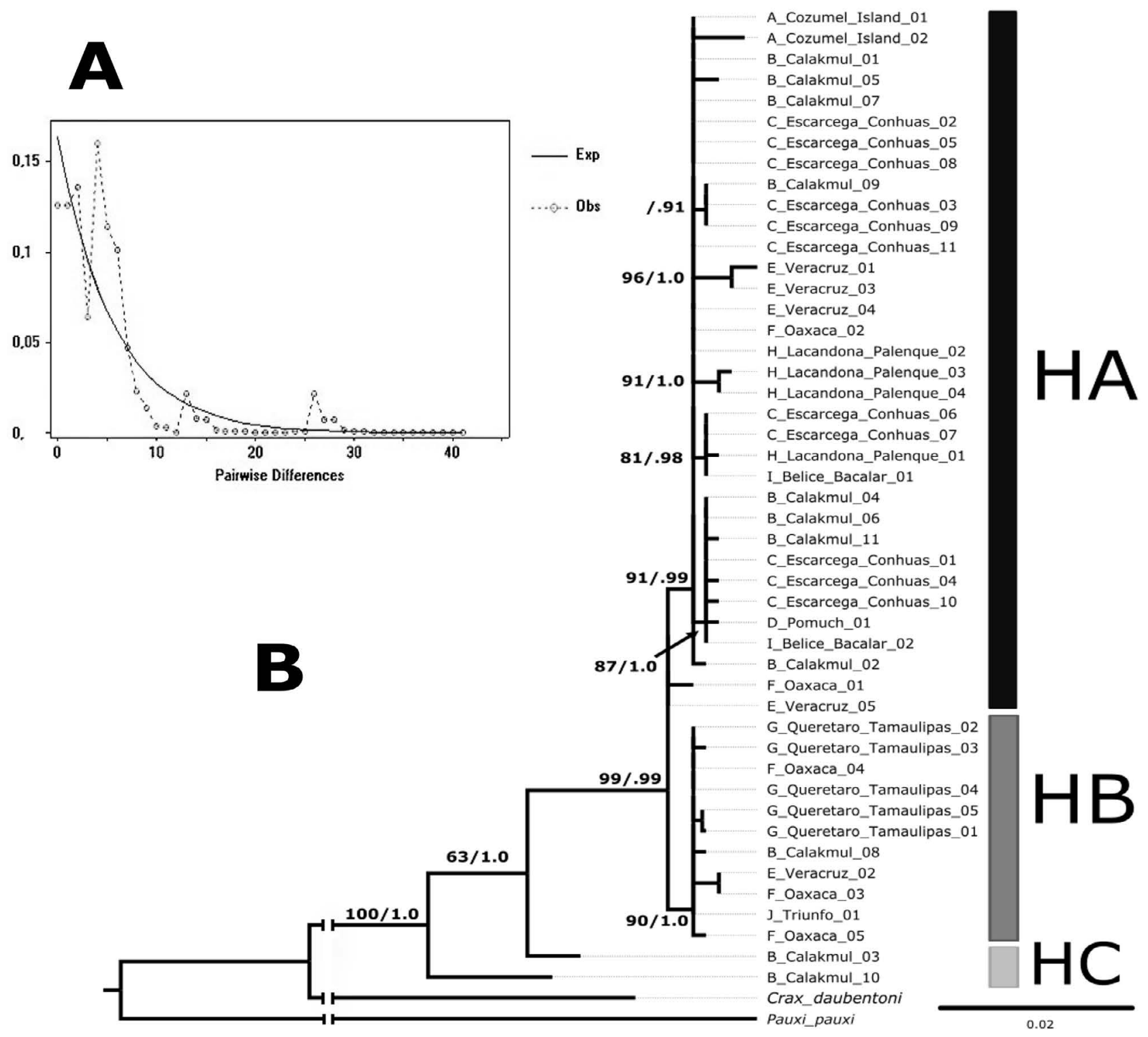

Figure 2. (A) Mismatch distribution of three mitochondrial genes concatenated in the Mexican populations of the Great Curassow (Crax rubra). (B) ML tree with 2000 bootstrap replicates for individuals of wild Mexican populations of Great Curassow (Crax rubra). Bootstrap values and posterior probabilities of the Bayesian analysis are found in the branches of the tree. The dotted gray bar separates the northern haplogroup (HA) from the eastern haplogroup (HB). 
On the other hand, in the southern portion of the distribution range, genetic flow has been high between regions; however, these areas are no longer connected.

Populations of curassows had high levels of gene flow, and a low genetic structure: This may also be due to a slow evolution rate because the species is a large long-lived bird (Nunn \& Stanley, 1998). On the one hand, C. rubra possibly presents a polygamous reproduction system (Alvarez-Prada \& Ruiz-García 2015) and thus is able to maintain levels of considerable genetic diversity. Coupled with its limited exclusivity for a given habitat, the species can maintain gene flow and therefore a low genetic structure. The Great Curassow can inhabit different types of tropical vegetation (e.g., deciduous forests; sub-deciduous, evergreen, and sub-evergreen forests; montane tropical forests; natural pastures; and mangroves), provided that they are conserved, a key feature for maintaining a high gene flow. High levels of genetic diversity were also found in Crax globulosa in three Amazonian islands (Ruiz García et al., 2007).

Although the habitat is degraded, no genetic evidence exists yet of habitat fragmentation. The low genetic differentiation among the included populations, even among the most distant, seems to indicate that the time elapsed since the fragmentation is very recent, so the populations have not yet differentiated clearly at the genetic level. On the other hand, the low rates of mitochondrial evolution in recent lineages in cracids has resulted in a low population genetic structure (van Tuinen \& Dike, 2004; Pereira et al., 2004). Fragmentation and loss of habitat are very recent processes in the evolutionary history of a species; therefore, the use of more variable markers such as microsatellites or SNPs is advisable to identify greater variability in the parameters (Allendorf et al. 2010; Guichoux et al., 2011), or in the markers subject to selection (i.e., Hemmer-Hansen et al., 2007).

The Cozumel Curassow maintains a low genetic differentiation from C. r. rubra. The two included samples with different haplotypes: one island exclusive and the other shared with mainland samples does not support differentiation. In contrast, other island species such as the Pygmy Raccoon (Procyon pygmaeus) and the Dwarf Coati (Nasua nelsoni) have haplotypes exclusive to Cozumel and not shared with the continent populations (McFadden et al., 2008). The presence of an exclusive Cozumel haplotype (yellow) in the Cozumel Curassow may still signal an incipient genetic differentiation with the continental population, as has been observed in other endemic island birds (RojasSoto et al., 2010). While adaptation to the ecological conditions of the island may be reflected in the small size of the Cozumel Curassow, this particular adaptation may be the result of different selection pressures (Mayr, 1963). A more complete sampling is essential to corroborate whether this haplotype is exclusive to the island.

The Great Curassow does not fly long distances, so the origin of its presence in Cozumel is unknown. On the one hand, Cozumel is an oceanic island that originated between the Oligocene and the Pliocene, and it has not been connected to the continent, which was submerged when the sea level increased $121,000 \pm 6,000$ years ago (Spaw, 1978; Weidie, 1985). Its distribution may be the result of an intentional introduction by the Maya people like it has occurred with other species of large game birds such as Meleagris gallopavo and $M$. ocellata (Hamblin, 1980).

Both endemics species, the coati and the raccoon inhabited Cozumel Island for several thousand years, as evidenced by fossils
(Hamblin, 1984). However, in recent excavations, bones of Crax rubra and of domestic birds such as Meleagris gallopavo and other species, were found on the island, which demonstrate a long-distance trade route. Species important to human diets were also confirmed, as were animals of other possible cultural, religious, or ceremonial use. (Hamblin, 1980). These deposits date back to the Late Postclassic period, that is, 800 years ago. In Cozumel, C. rubra has been recorded in six archaeological sites. However, it was apparently used only as food, and not as offerings (Hamblin, 1980).

With respect to the two haplotypes found in the population of Calakmul-Escárcega, which are highly differentiated from the other individuals $(0.9 \%$ and $0.5 \%$ in the three included genes, 24 and 11 steps away from the other predominant haplogroups, Figure 1), this result corresponds to other reports of high intrapopulation genetic diversity that have been found in Neotropical birds, such as in Amazilia tzacatl (Miller et al., 2011), Henicorhina leucosticta (Aguilar et al., 2016) or in Arremon aurantiirostris (López et al., 2016). This haplotypic diversity suggests, in the first instance, the possibility of cryptic species, but a closer analysis of the phenotypic and ecological differentiation indicates that these diversity patterns may have been generated by modifications in the distribution of habitats due to climatic changes. These changes could have varied the configuration of barriers, allowing populations to expand and have secondary contacts, becoming sympatric, and sharing haplotypes that had previously differentiated. This seems to be exactly what occurred in the Mayan jungle in the populations of Ara macao (Schmidt, 2013). Other examples of secondary contacts in neotropical birds of lowland habitats are being found (e.g., Brumfield, 2005; Miller et al., 2008, 2010; Vázquez-Miranda, 2009). These findings show a pattern of geographic isolations followed by secondary contacts, without leading to the formation of biological species and which are also not congruent with the nominal subspecies.

Analyzing the role of barriers in the diversification of taxa from the lowlands (Weir, 2006) and the mountains (Weir, 2009) it has been shown that mountain taxa have a wide range of divergence times. These findings support a history of extensive dispersion after the formation of the barrier, detected for species such as the Azure-crowned Hummingbird (Amazilia cyanocephala) (Rodríguez-Gómez \& Ornelas, 2013) or Lepidocolaptes affinis (Arbelaez-Cortés et al., 2010), which found in the Isthmus of Tehuantepec a permeable barrier, or the Common BushTanager (Chlorospingus ophthalmicus) where a very different marked population differentiation was found between the different mountain ranges (García-Moreno et al., 2004). This finding is also mentioned by Barber and Klicka (2010), who found two pulses of diversification across the Isthmus of Tehuantepec in 10 mountain taxa, both within the Pleistocene or late Pleistocene.

However, for lowland taxa, a tendency exists for the rate of diversification to decrease (Weir, 2006), suggesting that habitat alterations due to global climate were not sufficient to trigger an increase in the diversification rate of lowland faunas. This finding agrees with our work on Crax rubra, where we found that the differentiation across the Isthmus of Tehuantepec is not complete and suggests only an incipient differentiation by distance.

Noninvasive sample collection was an effective tool for the analysis of the genetic diversity of an elusive and endangered species such as C. rubra. Despite the loss of habitat and overexploitation to which 
the Great Curassow has been subjected, wild populations persist, with significant genetic variability, in the natural protected areas visited. The results indicate that the low genetic population differentiation is a consequence of historical gene flow, and to maintain genetic flow, connectivity must be maintained among populations. Since the only barriers that create isolated populations are anthropogenic, it is important to design conservation plans that highlight the need to maintain populations of considerable sizes, with these populations ultimately being connected to avoid isolation and subsequent loss of genetic diversity. Implementation of a constant monitoring system is needed in places where the populations of Great Curassow have been drastically reduced to prevent hunting, illegal trafficking, and nest poaching, because the overexploitation in some places was very evident. Additionally, planning for education campaigns that are inclusive in nature and address the current distribution of the curassow is important.

Although C. r. griscomi does not present the same level of differentiation as other Cozumel endemics such as the raccoon and coati, maintaining the distinction of this subspecies as an evolutionary unit while genetic studies are improved is important. More studies are needed on the genes subject to selection that have been detected using SNP markers. Such studies will help clarify whether the morphological differentiation found has developed with an evolutionary adaptive base since the species arrival on the island, and whether the subspecies evolved in isolation from major exchange events with its congeners on the continent. In this way, the conservation priority of the subspecies is maintained while better information is produced.

\section{Supplementary material}

The following online material is available for this article:

Table S1- Samples of wild Mexican populations of the Great Curassow (Crax rubra) used in the present study, indicating the taxonomic level, key for the assigned geographical group, type of sample (feather, blood, or tissue), collection site, geographic coordinates, and access numbers in GenBank. The female individuals of barred phase were assigned $(*)$.

Figure S1- Genetic distance matrix between individuals of the Mexican populations of the Great Curassow (Crax rubra), grouped according to their populations. The color ranges from lighter blue $(0 \%)$ (0) to navy blue $(1.0 \%)$.

\section{Author Contributions}

Jonathan Morales Contreras, contributed in data collection, data analysis and interpretation, and in manuscript preparation

Patricia Escalante Pliego contributed with data analysis and interpretation, manuscript preparation, and critical revision

Noemí Matías-Ferrer contributed in data collection, data analysis and interpretation, manuscript preparation, and critical revision

\section{Conflicts of interest}

The authors declare that they have no conflict of interest related to the publication of this manuscript.

\section{References}

AGUILAR, C., DE LÉON, L.F., LOAIZA, J.R., MCMILLAN, W.O. \& MILLER, M.J., 2016. Extreme sequence divergence between mitochondrial genomes of two subspecies of White-breasted Wood-wren (Henicorhina leucosticta, Cabanis, 1847) from western and central Panama. Mitochondr DNA 27(2): 956-957.

ALLENDORF, F. W., HOHENLOHE, P. A. \& LUIKART G. 2010. Genomics and the future of conservation genetics. Nature Rev. Genet. 11, 697-709.

ALVAREZ-PRADA, D. \& RUIZ-GARCÍA, M. 2015. Population genetics of the endangered Wattled Curassow (Crax globulosa, Cracidae, Aves) of the Colombian-Peruvian Amazon using microsatellites and ND2 mitochondrial. Stud. Neotrop. Fauna E. 50(2):1-16.

ARANDA, M. \& SÁNCHEZ-CORDERO, V. 1996. Prey spectra of Jaguar (Panthera onca) and Puma (Puma concolor) in tropical forests of Mexico. Stud. Neotrop. Fauna \& Environm. 31:65-67.

ARBELÁEZ-CORTÉS, E., NYÁRI, Á.S. \& NAVARRO-SIGÜENZA, A.G. 2010. The differential effect of lowlands on the phylogeographic pattern of a Mesoamerican montane species (Lepidocolaptes affinis, Aves: Furnariidae). Mol. Phylogenet. Evol., 57(2): 658-668.

BANDELT, H. J., FOSTER, P. \& RÖHL, A. 1999. Median-joining networks for inferring intraspecific phylogenies. Mol. Biol. Evol., 16(1): 37-48.

BARBER, B.R. \& KLICKA, J. 2010. Two pulses of diversification across the Isthmus of Tehuantepec in a montane Mexican bird fauna. Proceedings of the Royal Society of London B: Biological Sciences, p.rspb20100343.

BARKER, F. K. 2004. Monophyly and relationships of wrens (Aves: Troglodytidae): a congruence analysis of heterogeneous mitochondrial and nuclear DNA sequence data. Mol. Phylogenetic. Evol., 31, 486-504.

BAUR, E. H. 2008. Structure of a lowland neotropical galliform bird guild. MSc. Dissertation. University of Florida. Gainesville, EUA.

BEGAZO, A. 1997. Use and conservation of the Cracidae in the Peruvian Amazon. In STRAHL, S., BEUJON, S., BROOKS, D., BEGAZO, A., SEDAGHATKISH \& OLMOS, F. The Cracidae: Their biology and conservation. Washington, D. C.: Hancock house. 449-459.

BIRDLIFE INTERNATIONAL. 2016. Crax rubra. The IUCN Red List of Threatened Species 2016: e.T22678521A92776389. http://dx.doi. org/10.2305/IUCN.UK.2016.RLTS.T22678521A92776389.en. Downloaded on 31 August 2017.

BRUMFIELD, R.T., 2005. Mitochondrial variation in Bolivian populations of the Variable Antshrike (Thamnophilus caerulescens). The Auk, 122(2): 414-432.

CHINCHILLA, F. A. 1997. La dieta del Jaguar (Pantera onca) Puma (Puma concolor) y el manigordo (F. parduelis), (Carnivora, Felidae) en el Parque Nacional Corcovada. Rev. Biol. Trop. 45(3): 1223-1229.

CUARÓN, A. D., VALENZUELA-GALVÁN, D., GARCÍA-VASCO, D. et al. 2009. Conservation of the endemic dwarf carnivores of Cozumel Island, México. Small. Carniv. Conserv. 41: 15-21.

DELACOUR, J \& AMADON, D. 2004. Curassows and Related Birds. Second ed. Lynx Editions and The National Museum of Natural History, España y Estados Unidos de América. Pp. 476

DEL HOYO, J., ELLIOTT, A., SARGATAL, J. \& CABOT, J. 1994. Handbook of the birds of the world. Volumen dos. Lynx Edicions. España.

GARCÍA-MORENO, J., NAVARRO-SIGÜENZA, A.G., PETERSON, A.T. \& SÁNCHEZ-GONZÁLEZ, L.A. 2004. Genetic variation coincides with geographic structure in the common bush-tanager (Chlorospingus ophthalmicus) complex from Mexico. Mol Phylogenet. Evol., 33(1): 186-196.

GONCALVES E. C., FERRARI, S. F., BASTOS, H. B., WAJNTALA., ALEIXO, A. \& SCHNEIDER, M. P. C. 2010. Comparative genetic diversity of wild and captive populations of the bare-faced Curassow (Crax fasciolata) based on cross-species microsatellite markers: implications for conservation and management. Bioch. Genet. 48: 472-479.

GUICHOUX, E., LAGACHE, L., WAGNER, S., CHAUMEIL, P., LÉGER, P., LEPAIS, O., LEPOITTEVIN, C., MALAUSA, T., REVARDEL, E., SALIN, F. \& PETIT, R. J. 2011. Current trends in microsatellite genotyping. Mol. Ecol. Res. 11, 591-611. 
GUINDON S., DUFAYARD J.F., LEFORT V., ANISIMOVA M., HORDIJK W. \&GASCUEL O. 2010. New Algorithms and Methods to Estimate MaximumLikelihood Phylogenies: Assessing the Performance of PhyML 3.0. Syst. Biol. 59(3):307-21, 2010.

HACKETT, S. 1996. Molecular Phylogenetics and Biogeography of Tanagers in the Genus Ramphocelus (Aves). Mol. Phylogenet. Evol., 5(2): 368-382.

HAMBLIN, N. L. 1980. Animal utilization by the Cozumel Maya: interpretation through faunal analysis. Doctoral Dissertation The University of Arizona. Estados Unidos.

HAMBLIN, N.L. 1984. Animal use by the Cozumel Maya. Tucson: The University of Arizona Press. Arizona. Estados Unidos. 206 pp.

HANSEN, M.C., POTAPOV, P.V., MOORE, R., HANCHER, M., TURUBANOVA, S.A., TYUKAVINA, A.,THAU, D., STEHMAN, S.V., GOETZ, S.J., LVOELAND, T.R., KOMMAREDDY, A., EGOROV, A.,CHINI, L., JUSTICE, C.O. \& TOWNSHEND, J.R.G., 2013. High-resolution global maps of 21st-century forest cover change. Science 342, 850-853.

HARSHMAN, J. 1996. Phylogeny, Evolutionary Rates, and Ducks. Ph. D. Thesis, University of Chicago.

HEMMER-HANSEN, J., NIELSEN, E. E., FRYDENBERG, J. \& LOESCHCKE, V. 2007. Adaptive divergence in a high gene flow environment: Hsc70 variation in the European flounder (Platichthys flesus L.). Heredity 99, 592-600.

HERBERT, P., STOECKLE, M., ZEMLAK, T. \& FRANCIAS, C. 2004. Identification of birds through DNA Barcodes. PloS Biol., 2(10): e312

HERNÁNDEZ-PÉREZ, E., MARTÍNEZ-MORALES, M. A., TOBÓNSAMPEDRO, A., PINILLA-BUITRAGO, G., SANVICENTE, M. \& REYNA-HURTADO, R. 2014. Registros notables que amplían la distribución de dos especies de Crácidos en la península de Yucatán, México. Ornitol. Neotrop. 25, 291-301.

HOSNER, P. A., BRAUN, E. L. \& KIMBALL R. T. 2016. Rapid and recent diversification of curassows, guans, and chachalacas (Galliformes: Cracidae) out of Mesoamerica: Phylogeny inferred from mitochondrial, intron, and ultraconserved elements sequences. Mol. Phylogenet. Evol. 102:320-330.

ISARRI, I. \& ZARDOYA, R. 2013. Phylogeny Reconstruction. In: eLS. John Wiley \& Sons, Ltd: Chichester. DOI: 10.1002/9780470015902.a0001521

IOU (International Ornithological Union). 2018. (C) 2018 IOC World Bird List Updated 31-Jul-2017 with version 7.3 IOC World Bird List by Frank Gill \& David Donsker (Eds). Accessed on 17 Jan 2018.

KATTAN, G. H., MUÑOZ, M. C. \& D. W. KIKUCHI. 2015. Population densities of curassows, guans, and chachalacas (Cracidae): Effects of body size, habitat, season, and hunting. The Condor 118.1: 24-32.

KERR, K. C. R., LIJTMAER, D. A., BARREIRA, A. S., HERBERT, P. D. \& TUBARO, P. L. 2009. Probing evolutionary patterns in Neotropical birds through DNA barcodes. PLos One: 4e4379. doi: 10.1371/journal. pone. 0004379 .

KOCHER, T.D., THOMAS, W.K., MEYER, A., EDWARDS, S.V., PÄÄBO, S., VILLABLANCA, F.X. \& WILSON, A.C. 1989. Dynamics of mitochondrial DNA evolution in animals: Amplification and sequencing with conserved primers. Proc. Natl. Acad. Sci. U.S.A. 86: 6196-6200.

KOLEFF, P., URQUIZA-HAAS, T. \& CONTRERAS, B. 2012. Prioridades de conservación de los bosques tropicales en México: reflexiones sobre su estado de conservación y manejo. Ecosistemas 21(1-2): 6-20.

LEIGH, J. W. \& BRYANT D. 2015. PopART: Full-feature software for haplotype network construction. Methods. Ecol. Evol. 6(9):1110-1116.

LIBRADO, P. \& ROZAS, J. 2009. DnaSP v5: A software for comprehensive analysis of DNA polymorphism data. Bioinformatics, 25(11): 1451-1452

LIJTMAER, D. A., KERR, K. C. R., STOECKLE, M. Y. \& TUBARO, P. L. 2012. DNA Barcoding Birds: From Field Collection to data Analysis. In: KRESS, W. J. \& ERICKSON, D. L. (Eds.) DNA Barcodes: Methods and Protocols, Springer, New York, 127-152.

LOPEZ, K., ANGELI, C., AGUILAR, C., LOAIZA, J.R., DE LEÓN, L.F., MCMILLAN, W.O. \& MILLER, M.J., 2016. Extreme mitogenomic divergence between two syntopic specimens of Arremon aurantiirostris (Aves: Emberizidae) in central Panama suggests possible cryptic species. Mitochondrial DNA Part A, 27(5): 3451-3453.
MADDISON, W. P. \& D.R. MADDISON. 2011. Mesquite: a modular system for evolutionary analysis. Version 2.75 . http://mesquiteproject.org.

MARTINEZ-MORALES, M. A. 1996. The Cozumel Curassow: abundance, habitat preference and conservation. MSc. Dissertation. University of Cambridge, Reino Unido. 82 p.

MARTINEZ-MORALES, M. A. 1999. Conservation status and habitat preferences of the Cozumel Curassow. Condor 101:14-20

MARTINEZ-MORALES, M. A., CRUZ, P. C. \& CUARÓN, A.D. 2009. Predicted population trends for Cozumel Curassows (Crax rubra griscomi): empirical evidence and predictive models in the face of the climates change. J. Field Ornithol. 80(4): 317-327.

MAYR, E. 1963. Speciation phenomena in birds. Am. Nat. 74:249-278.

MCFADDEN, K. W., GOMPPER, M. E., VALENZUELA, D. G. \& MORALES J. C. 2008. Evolutionary history of the critically endangered Cozumel dwarf carnivores inferred from mitochondrial DNA analyses. J. Zool. 276: 176-186.

MILLER, M.J., BERMINGHAM, E., KLICKA, J., ESCALANTE, P., DO AMARAL, F.S.R., WEIR, J.T. \& WINKER, K. 2008. Out of Amazonia again and again: episodic crossing of the Andes promotes diversification in a lowland forest flycatcher. Proceedings of the Royal Society of London B: J. Biol. Sci. 275(1639): 1133-1142.

MILLER, M.J., BERMINGHAM, E., KLICKA, J., ESCALANTE, P. \& WINKER, K. 2010. Neotropical birds show a humped distribution of within-population genetic diversity along a latitudinal transect. Ecol. Lett. 13(5): 576-586.

MILLER, M.J., LELEVIER, M.J., BERMINGHAM, E., KLICKA, J.T., ESCALANTE, P. \& WINKER, K. 2011. Phylogeography of the Rufoustailed Hummingbird (Amazilia tzacatl). The Condor, 113(4): 806-816.

MORALES-CONTRERAS, J., ESCALANTE, P., MARTÍNEZ-RUÌZ, M. \& MATÍAS-FERRER, N. 2016. Black hawk-eagle (Spizaetus tyrannus) identified by DNA from a feather recovered in the rain-forest region of Veracruz. Southwest. Nat., 61(2): 133-159.

MUÑOZ, M. \& KATTAN, G. H. 2007. Diets of cracids: How much do we know? Ornitol. Neotrop. 18(1): 21-36.

NUNN, G. B. \& STANLEY, S. E. 1998. Body Size Effects and Rates of Cytochrome b Evolution in Tube-Nosed Seabirds. Mol. Biol. Evol., 15(10) 1360-1371.

NELSON, E. W. 1926. Two new birds from Mexico. P. Biol. Soc. of Wash. 39:105-108.

PEREIRA, S. L., \& BAKER, A. J. 2004a. Low number of mitochondrial pseudogenes in the chicken (Gallus gallus) nuclear genome: implications for molecular inference of population history and phylogenetics. BMC Evolutionary Biology, 4(1), 17.

PEREIRA, S. L. \& BAKER A. J. 2004b. Vicariant speciation of curassows (Aves, Cracidae): a hypothesis based on mitochondrial DNA phylogeny Systematic Biology. The Auk, 121 (3): 682-694.

PEREIRA, S. L., GRAU, E. T. Y WAJNTAL, A. 2004. Molecular architecture and rates of DNA substitutions of the mitochondrial control region of cracid birds. Genome, 47:535-545.

PEREIRA, S. L. \& WANJTAL, A. 2001. Estimates of the genetic variability in a natural population of bare-faced curassow, Crax fasciolata (Aves, Galliformes, Cracidae). Bird. Conserv. Int. 11:301-308.

PÉREZ-IRINEO, G., \& A. SANTOS-MORENO. 2017. Occupancy, relative abundance, and activity patterns of Great Curassow (Crax rubra) in southeastern Mexico. Ornitol. Neotrop. 28: 313-320.

PETERSON, A. T., NAVARRO-SIGÜENZA, A.G., CUERVO-ROBAYO, A. P., BERLANGA H., \& SOBERÓN, J. 2015. Twentieth century turnover of Mexican endemic avifaunas: Landscape change versus climate drivers. Sci. Adv., 1,e1400071.

PINILLA-BUITRAGO, G., MARTÍNEZ-MORALES, M. A., GONZÁLEZGARCÍA, F., ENRÍQUEZ, P.L., RANGEL-SALAZAR, J.L., GUICHARDROMERO, C.A., NAVARRO-SIGÜENZA, A.G., MONTERRUBIO-RICO, T.C. \& ESCALONA-SEGURA, G. 2014. CracidMexI: a comprehensive database of global ocurrences of cracids (Aves, Galliformes) with distribution in Mexico. ZooKeys, 420: 87-115. 
POSADA, D. 2008. jModelTest: Phylogenetic Model Averaging. Mol. Biol Evol., 25 (7): 1253-1256.

REEVES, J. H. 1992. Heterogeneity in the substitution process of amino acid sites of proteins coded for by mitochondrial DNA. J. Mol. Evol. 35(1): 17-31.

RODRÍGUEZ-GÓMEZ, F. \& ORNELAS, J.F. 2013. Genetic divergence of the Mesoamerican azure-crowned hummingbird (Amazilia cyanocephala, Trochilidae) across the Motagua-Polochic-Jocotán fault system. J. Zool. Syst. Evol. Research. 52(2): 142-153.

ROJAS-SOTO, O. R., WESTBERG, M., NAVARRO-SIGÜENZA, A.G. \& ZINK, R. M. 2010. Genetic and ecological differentiation in the endemic avifauna of Tiburon Island. J. Avian Biol. 41: 398-406.

RONQUIST, F., HUELSENBECK, J.P. \& TESLENCKO, M. 2011. MrBayes: a program for the Bayesian inference of phylogeny. Version 3.2.

RUIZ-GARCÍA, M., MURILLO, A., CORRALES, C., ROMERO-ALEÁN, N., \& ALVAREZ-PRADA, D. 2007. Genética de poblaciones amazónicas: la historia evolutiva del jaguar, ocelote, delfín rosado, mono lanudo y piurí, reconstruida a partir de sus genes. Animal Biodiversity and Conservation, 30(2), 115-130.

SCHMIDT, K.L., 2013. Spatial and temporal patterns of genetic variation in scarlet macaws (Ara macao): implications for population management. In: La Selva Maya, Central America. Columbia University, New York Google Scholar.

SEDAGHATKISH, G. 1996. The importance of seed dispersers in the conservation of useful wild plant species: a case study of the avian family Cracidae. MSc. Dissertation. College Park, University of Marylan. USA. 122 p.

SEMARNAT (Secretaría de Medio Ambiente y Recursos Naturales). 2010. Norma Oficial Mexicana NOM-059-SEMARNAT-2010, Protección ambientalespecies nativas de México y de flora y faunas silvestres-categorías de riesgo y especificaciones para su inclusión, exclusión o cambio-lista de especies en riesgo. Diario oficial de la Federación. México, CDMX.

SILVA, J.L. \& STRAHL, S. 1997. Presión de caza sobre poblaciones de crácidos en los parques nacionales al norte de Venezuela. The Cracidae: Their biology and conservation. Hancock House Publishers Ltd. Surrey, BC and Blaine, WA. $437-438$.

SORENSON, M. D., AST, J. C., DIMCHEFF, D. E., YURI, T. \& MINDELL, D. P. 1999. Primers for a PCR-Based Approach to Mitochondrial Genome Sequencing in Birds and Other Vertebrates. Mol. Phyl. Evol., (12) 2:105-114.

SPAW, R.H. 1978. Late Pleistocene carbonate bank deposition: Cozumel Island, Quintana Roo, Mexico. Gulf Coast Assoc. Geol. Soc. 28, 601-619.
TAMURA, K., STECHER, G., PETERSON, D. \& KUMAR, S. 2013. Mega 6: Molecular evolutionary genetics analysis version 6.0. Mol. Biol. Evol., 30 (12): 2725-2729.

TAMURA, K. \& NEI, M. 1993. Estimation of the number of nucleotide substitutions in the control region of mitochondrial DNA in humans and chimpanzees. Mol. Biol. Evol., 10(3):512-526.

TAVARES, E. S. \& BAKER A. J. 2008. Single mitochondrial gene barcodes reliably identify sister-species in diverse clades of birds. BMC Evol. Biol., $8: 81$.

THOMPSON, J. D., GIBSON, T. J. \& HIGGINS, D. G. 2002. Multiple sequence alignment using ClustalW and ClustalX. Curr. Protoc. Bioinformatics $00: 2.3: 2.3 .1-2.3 .22$.

VAN TUINEN, M. \& DYKE, G. J. 2004. Calibration of galliform molecular clocks using multiple fossils and genetic partitions. Mol. Phyl. Evol., 30: 74-86.

VÁZQUEZ-MIRANDA, H., NAVARRO-SIGÜENZA, A.G. \& OMLAND, K.E. 2009. Phylogeography of the Rufous-naped Wren (Campylorhynchus rufinucha): Speciation and hybridization in Mesoamerica. The Auk, 126(4): 765-778.

WEIDIE, A.E. 1985. Geology of the Yucatan platform, part 1. In: WARD, W.C., WEIDIE A.E., BACK, W. (eds.) Geology andhydrogeology of the Yucatan and quaternary geology ofnortheastern Yucatan peninsula. New Orleans GeologicalSociety, New Orleans, pp 1-19.

WEIR, J.T. 2006. Divergent timing and patterns of species accumulation in lowland and highland neotropical birds. Evol. 60(4): 842-855.

WEIR, J.T. 2009. Implications of genetic differentiation in Neotropical montane forest birds. Annals of the Missouri Botanical Garden, 96(3): 410-433.

ZINK R. M., RISING, J. D., MOCKFORD, S., HORN, A. G., WRIGHT, J. M. LEONARD, M. \& WESTBERG, M. C. 2005. Mitochondrial DNA variation species, limits and rapid evolution of plumage coloration and size in the Savannah Sparrow. Condor. 107, 21-28.
Received: 07/09/2018

Revised: 07/12/2018

Accepted: 11/12/2018

Published online: 31/01/2019 